\title{
Pomen študij ranljivosti okolja za sonaravni razvoj Slovenije
}

\author{
Metka Špes \\ Dr., Oddelek za geografijo, Filozofska fakulteta, Univerza v Ljubljani, \\ Aškerčeva 2, 1000 Ljubljana, Slovenija \\ e-mail: metka.spes@uni-lj.si
}

\section{Izvleček}

Študija ranljivosti okolja temelji na oceni nosilnosti oziroma regeneracijski sposobnosti proučevanega okolja in njegovih pokrajinotvornih sestavin, upoštevane pa so tudi spremembe, ki jih z dosedanjimi posegi v okolje vnesel človek s svojimi raznovrstnimi dejavnostmi. Strokovno vrednotenje vseh kazalcev se združuje na optimalno homogenih pokrajinskih enotah in s tem predstavlja dobro podlago za načrtovanje sonaravnega razvoja.

Ključne besede: sonaravni razvoj, ranljivost okolja, nosilnost okolja, okoljski pritiski, presoje

\section{The Importance of Environmental Vulnerability Studies for the Sustainable Development of Slovenia}

\begin{abstract}
The study of environmental vulnerability proceeds from the assessment of the carrying capacity or regenerative capacity of the studied environment and its landscape-forming constituents. Changes brought about by human interventions into the environment, resulting from diverse human activities, are also taken into consideration. Expert evaluation of all of the indicators has been made for the optimally homogeneous landscape units, thus providing a good basis for the planning of sustainable development.
\end{abstract}

Key words: sustainable development, environmental vulnerability, carrying capacity, environmental impacts, assessment 


\section{UVOD}

Najpomembnejši dokument konference članic Združenih narodov o okolju in razvoju, ki je bila 1992 v Riu de Janeiru, je Agenda 21, v kateri so podrobneje opisani koncepti sonaravnega razvoja, ki ga je predhodno (1987) definirala Svetovna komisije za okolje in razvoj (WCED) v dokumentu Our Common future. Njihova najpreprostejša razlaga je, da je to razvoj, ki zadošča današnjim potrebam, ne da bi pri tem ogrožal možnosti prihodnjih generacij (Agenda 21 za Slovenijo, 1995). Agenda poziva vse države, da pripravijo svoje nacionalne strategije in akcijske načrte za uresničevanje načel sonaravnega, uravnoteženega razvoja. Osnovno načelo sonaravnosti je upoštevanje nosilne (regeneracijske) zmogljivosti okolja in razvoj dejavnosti, ki ohranjajo ekosistemsko stabilnost, vitalnost in pestrost narave ter korenito zmanjšajo izčrpavanje neobnovljivih virov.

Zakon o varstvu okolja, ki ga je junija 1993 sprejela Slovenija (Ur.l. RS 32/93), pomeni normativno podlago za uresničevanje in vključevanje načel sonaravnosti v razvoj naše države. Za geografijo in naše strokovno ter raziskovalno delo je pomembno predvsem 5. poglavje zakona, ki govori o raziskovanju, programiranju in planiranju na področju varstva okolja. V planiranje in načrtovanje človekovih dejavnosti, ki imajo posredne ali neposredne okoljske učinke, zakon uvaja tri instrumente. $Z$ njimi naj bi vse posege $v$ največji možni meri uskladili z zahtevami varstva okolja, predvsem pa $\mathrm{z}$ njegovo nosilnostjo oziroma samočistilnimi ter regeneracijskimi sposobnostmi. Izhajajo namreč iz spoznanja, da je okolje različno občutljivo na posamezne človekove posege. Prvi med temi predlaganimi instrumenti je študija ranljivosti okolja in na njej utemeljena stopnja varovanja okolja, v nadaljevanju gre za celovito presojo vplivov na okolje in na koncu še za presojo konkretnih in načrtovanih posegov na okolje (Čebulj et al., 1994).

Študije ranljivosti okolja so torej eden bistvenih in z zakonom določenih instrumentov preventivnega varovanja okolja, njihov namen in vsebino opredeljujeta 51. in 52. člen, ki predvidevata pripravo tovrstnih raziskav za ozemlje celotne države in prav tako tudi za občine ali skupine manjših lokalnih skupnosti. Namen študije je $\mathrm{z}$ optimalnim številom kazalcev in kriterijev oceniti ranljivost okolja in njegovih sestavin za potrebe načrtovanja bodočih posegov $\mathrm{v}$ okolje in usmerjanje prostorskega razvoja $\mathrm{v}$ izbrani pokrajinski enoti. Glede na to, da je upoštevanje ranljivosti pri načrtovanju posegov v okolje predpisano kot splošna obveznost, razumemo tovrstne študije kot dobro strokovno podlago za načrtovanje sonaravnega razvoja. To pa obenem pomeni, da bi morale vse presoje vplivov večjih posegov na okolje izhajati prav iz predhodnega poznavanja ranljivosti okolja. Obsežna in temeljita analiza vseh 
okoljskih dejavnikov, ki jo študija zahteva, pa posredno lahko pomeni dobro informacijsko podlago za pripravo planskih dokumentov na državni in lokalni ravni, predvsem pa za poročila o stanju okolja in programe varstva okolja.

Metodološka zasnova študij ranljivosti okolja, ki smo jih pripravili na Inštitutu za geografijo (Špes et all, 1996), temelji na načelih sonaravnosti in ohranjanju ekosistemske stabilnosti oziroma odpornosti, ki omogoča, da se ob kratkotrajnih zunanjih vplivih (šokih) narava sama obnavlja. Vsi naravni ali pretežno naravni ekosistemi težijo namreč k dolgoročni stabilnosti in imajo sposobnost, da se na zunanje vplive adaptirajo, jih absorbirajo oziroma jih nevtralizirajo in ustvarijo novo ravnovesje. S tem vzdržujejo dinamično ravnovesje, ki se poruši ob človekovih posegih, ki so premočni ali ko gre za hitre spremembe oziroma vplive aktivnosti, ki součinkujejo ali se sinergijsko dopolnjujejo ter tako spreminjajo tudi snovno-energetski pretok skozi ekosistem. Tako porušijo tudi sistemsko stabilnost in prinašajo nepričakovane ter nepredvidljive učinke, ki so v nasprotju s sonaravnim razvojem (Park, 1997).

Skica 1. Vzdrževanje dinamičnega ravnovesja za ohranjanje ekosistemske stabilnosti

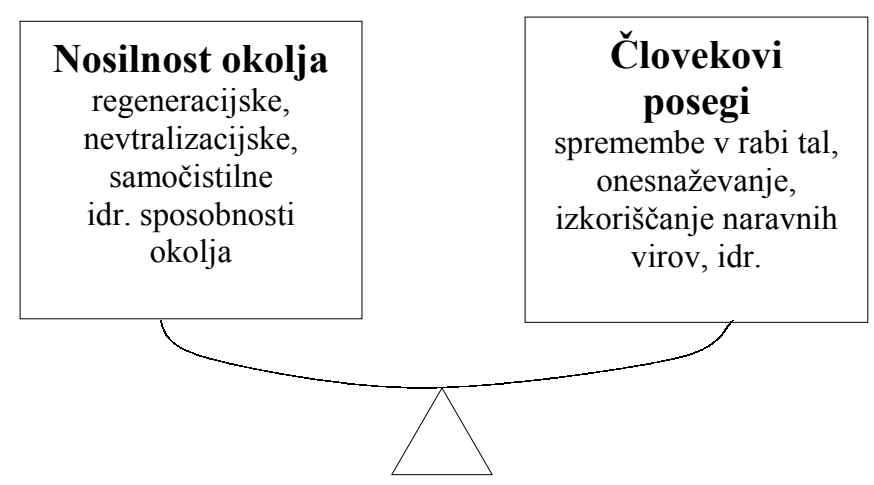

Pri študijah ranljivosti okolja zato na eno strani vrednotimo naravnogeografske kazalce, ki opredeljujejo nosilnost okolja in njegovih sestavin oziroma njihovo samočistilno, nevtralizacijsko sposobnost, na drugi strani pa dosedanje človekove posege $\mathrm{v}$ to okolje, spremembe $\mathrm{v}$ rabi tal in naravnih virov oziroma stopnjo obremenjenosti ali splošno onesnaženost in degradacijo. Upoštevamo posredne in neposredne kazalce. S tehtanjem - vrednotenjem obeh skupin okoljskih dejavnikov pa ocenimo ranljivost obravnavanega okolja in njegovih pokrajinotvornih sestavin oziroma predlagamo stopnjo varovanja okolja in oceno še sprejemljivega obremenjevanja. 
Namen študij je prikazati stopnjo ranljivosti okolja kot celote in njegovih pokrajinotvornih sestavin, zato podrobneje analiziramo zrak, vode (površinske in podtalnico), relief z litologijo, prsti in naravno vegetacijo (gozd). Družbenogeografske karakteristike in osnovne značilnosti pokrajinske rabe prostora pa obravnavamo $v$ funkcijski povezavi s stanjem naravnogeografskih pokrajinotvornih elementov oziroma njihove pokrajinske učinke $\mathrm{z}$ vidika ocenjevanja obremenjenosti (emisije, ostale obremenitve in motnje kot posledica človekovih dejavnosti).

\section{Skica 2: Vsebina študije ranljivosti okolja}

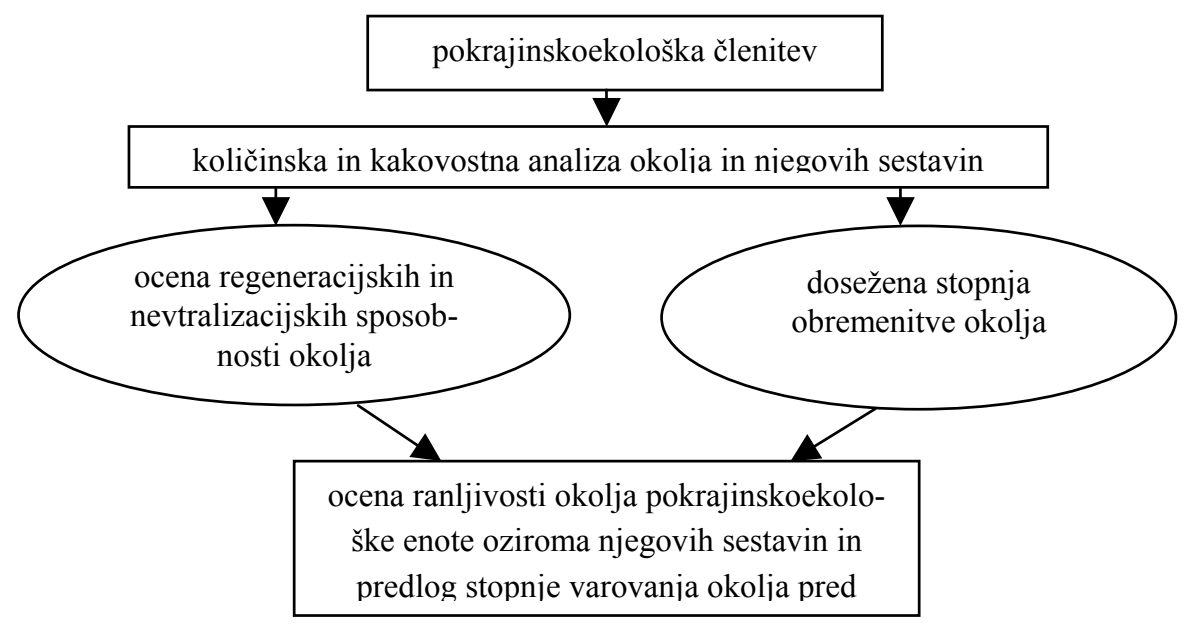

\section{POKRAJINSKOEKOLOŠKE ČLENITVE}

Zakon o varstvu okolja predvideva v 52. členu, da je pri študiji ranljivosti okolja potrebna predhodna členitev (ekosistemska) obravnavanega območja na optimalno homogene regije. Njihova valikost in število zavisi od velikosti obravnavanega območja oziroma nivoja izdelave študije ranljivosti. Pri dosedanjih študijah ranljivosti okolja, ki smo jih geografi pripravili za vzorčna območja $v$ različnih slovenskih pokrajinah, se je izkazala kot najprimernejša pokrajinskoekološka členitev $\mathrm{z}$ upoštevanjem dominantnih-nosilnih elementov okolja, tistih torej, ki imajo večji vpliv tudi na človekovo delovanje in pokrajinsko rabo. Med njimi smo upoštevali tako stabilne pokrajinskoekološke dejavnike členitve (npr.: reliefne značilnosti, litološko zgradbo), kot variabilne (npr.: podnebje, hidrološke značilnosti, prst, itd.). Dominantni elementi okolja niso enaki $v$ vseh pokrajinah. $\mathrm{V}$ večjem delu Slovenije je relief predvsem $\mathrm{z}$ 
višinsko slojevitostjo dominanten element okolja in predstavlja temelj členitve za Alpsko in Predalpsko Slovenijo, medtem ko je za Dinarskokraško dominantna litološka zgradba in z njo povezani kraški pojavi. Pri Panonski in Sredozemski Sloveniji je v ospredju podnebje, šele v drugi fazi pa relief in deloma litološka zgradba.. V ravninskih območjih je lahko dominanten element kamninska zgradba (različne vrste naplavin) in od nje odvisne talne razmere, rastje, raba tal (Natek, 1996, v študiji Špes et al.). V geografsko in ekološko zelo pestri Sloveniji so pokrajinskoekološke enote izraziti pokrajinski spleti, mozaiki zelo različnih ekotopov, ki pa so znotraj enot razporejeni po določenih naravnih zakonitostih. Za oceno ranljivosti okolja, ki mora upoštevati naravnogeografske in družbenogeografsek značilnosti obravnavane pokrajine, je pomembno, da pokrajinskoekološka regionalizacija izhaja iz razumevanje ekosistemske povezanosti in součinkovanja vseh sestavin okolja.

Za študij ranljivosti okolja na lokalni ravni je Slovenija razčlenjena na 205 pokrajinskoekoloških enot (Natek, 1996, v študiji Špes et al.). Jasni kriteriji regionalizacije omogočajo tudi nadaljnje in podrobnejše pokrajinskoekološke členitve ali pa njihovo združevanje v pokrajinske tipe. Pri vzorčnih študijah ranljivosti okolja, ki smo jih izdelali za nekdanji občini Škofja Loka (Špes et al., 1994), Novo mesto (Špes et al., 1995), za občine Spodnjega Podravja (Brečko et al., 1996) ter občino Koper (Špes et al., 2001) smo ugotovili, da smo z obstoječo regionalizacijo dobili relativno homogene pokrajinske enote. Strokovno korektnejša pa je vsekakor ocena ranljivosti za manjše enote, vendar se ob tem pojavi že problem minimalnega števila potrebnih količinskih podatkov in informacij za oceno ranljivosti okolja $\mathrm{v}$ tako majhnih enotah.

Rezultat dosedanjih geografskih proučevanj je tudi poizkus ocene ranljivosti okolja za celotno ozemlje Slovenije razdeljene na $13+1$ pokrajinskoekoloških tipov (13 tipov + morje v Tržaškem zalivu). To so pokrajinske enote, za katere smo v predhodnih raziskavah ugotovili, da se približno enako odzivajo na različne človekove vplive, se pravi, da imajo "podobne nosilne sposobnosti”. Pokrajinskoekološka tipizacija se od pokrajinskoekološke členitve razlikuje po tem, da niso v ospredju razlike med sosednjimi območji, temveč skupne značilnosti posameznih, tudi prostorsko oddaljenih delov ozemlja. Meje pokrajinskoekoloških enot in pokrajinskih tipov so skladne (znotraj pokrajinskih tipov so zokrožene skupine pokrajinskoekoloških enot). S to členitvijo smo še vedno ohranili preglednost nad značilno pokrajinsko pestrostjo naše države, na drugi strani pa nam manjše število prostorskih enot omogoča hitrejšo, a za določene načrtovalske potrebe še vedno ustrezno oceno ranljivosti okolja za celo Slovenijo (Natek, 1999, v študiji Špes et al.). 


\section{KOLIČINSKA IN KAKOVOSTNA ANALIZA OKOLJA}

Za vsako pokrajinskoekološko enoto ali pokrajinski tip je narejena kakovostna in količinska analiza okolja in njegovih sestavin. Temelji na funkcijskem vrednotenju ustreznih fizično - in družbenogeografskih (posrednih in neposrednih) kazalcev. To je obenem tudi najobsežnejši in najzamudnješi del raziskave, saj temelji na zbiranju podatkov, informacij ter njihovem vrednotenju. Izhajajoč iz raziskovalnih izkušenj pri vzorčnih proučevanjih, smo število kazalcev in velikost razredov optimalno prilagodili našim razmeram in podatkovnim bazam.

\section{OCENA REGENERACIJSKIH IN NEVTRALIZACIJSKIH SPOSOBNOSTI OKOLJA}

$\mathrm{Za}$ oceno nosilne sposobnosti (samočistilne, nevtralizacijske, regeneracijske sposobnosti) obravnavane pokrajinskoekološke enote ali pokrajinskega tipa oziroma posamezne pokrajinotvorne sestavine funkcijsko vrednotnotimo naravnogeografske značilnosti oziroma fizičnogeografske kazalce. Izbrali smo le tiste, ki neposredno vplivajo na nevtralizacijske sposobnosti zraka(npr. veter, megla, inverzija za opredeljevanje samočistilnih sposobnosti zraka), površinskih in talnih vod, prsti, reliefa, naravne vegetacije in okolja kot celote.

\section{DOSEŽENA STOPNJA OBREMENITVE OKOLJA}

Kazalci za tovrstno vrednotenje so izbrani tako, da z njimi ocenimo že doseženo stopnjo preoblikovanosti naravnega ekosistema oziroma posameznih pokrajinotvornih sestavin. Tu gre predvsem za vplive raznovrstnih človekovih dejavnosti, ki so bolj ali manj agresivno posegle $\mathrm{v}$ pokrajino in $\mathrm{s}$ tem tudi zmanjšale njeno nosilno sposobnost oziroma nevtralizacijske sposobnosti posameznih setavin. Pri tem vrednotenju uporabljamo neposredne in posredne družbenogeografske kazalce, ki kažejo na obremenjevnje okolja. Med njimi so specifični kazalci za obremenjevanje posameznih sestavin okolja ter univerzalnejši, ki se lahko uporabljajo pri več pokrajinotvornih sestavinah in nenazadnje tudi kompleksni, ki kažejo na součinkovanje več dejavnosti. Za natančnejše študije ranljivosti okolja $v$ manjših pokrajinskoekoloških enotah je izbrano večje število kazalcev za obremenjevanje in obremenjenost vseh pokrajinotvornih elementov. Za študije ranljivosti pokrajinskih tipov pa so določeni univerzalnejši oziroma kompleksni kazalci obremenjevanja okolja, ki 
kažejo na večplastno in raznovrstno obremenjevanje posameznih človekovih dejavnosti na vse sestavine okolja.

\section{OCENA RANLJIVOSTI POKRAJINSKOEKOLOŠKE ENOTE IN NJENIH SESTAVIN TER PREDLOG STOPNJE VAROVANJA OKOLJA PRED OBREMENITVAMI}

Strokovno, celovito in kompleksno vrednotenje razmerja med nosilno zmogljivostjo okolja in splošno onesnaženostjo oziroma dosežene stopnjo obremenitve je podlaga za sintezno oceno in ponazoritev ranljivosti ne le posameznih sestavin okolja (zrak, vode, relief, prst, gozd), ampak pokrajinskoekološkete v celoti. Rezultati vrednotenja omogočajo tudi izpostavitev najbolj ranljivih sestavin v vsaki pokrajinski enoti, ki so obenem tudi najbolj izstopajoči omejitveni dejavniki za nadaljnji prostorski razvoj oziroma načrtovanje novih antropogenih vnosov v to okolje. Sintezna ponazoritev ranljivosti okolja in njegovih sestavin daje tudi dobro strokovno podlago za pripravo predlogov stopnje varovanja okolja in preventivnega planiranja.

Pri vrednotenju posameznih pokrajinskih elementov se predvideva uporaba interakcijske matrike, kjer si vsi kazalci opredeljeni s štirimi količinskimi ali kakovostnimi razredi. Njihov seznam je prilagojen slovenskim razmeram, stopnji raziskanosti posameznih pokrajinskih pojavov in podatkovnim podlagam. Pri združevanju vseh kazalcev in kriterijev v štiri razrede smo izhajali iz strokovnih ocen specialistov in raziskovalnih izkušenj pri vzorčnih raziskavah. Z jasno definiranimi in omejenimi razredi se študije ranljivosti okolja metodološko in vsebinsko poenotijo za vse lokalne raziskave, zagotovi se tudi objektivnost pri ocenjevanju stanja okolja in možnost primerjave podatkov za različne prostorske enote. Izognemo pa se tudi morebitnemu nestrokovnemu ali namernemu precenjevanju ali zmanjševanju pomena posameznih informacij o stanju okolja.

Skupni kriteriji za opredeljevanje mejnih vrednosti posameznih razredov v matriki:

- razred 1 pomeni pri količinski in kakovosti analizi okolja malo, nepomembno, komaj zaznavno, največjo nosilnost okolja in majhno celotno obremenjenost okolja, zmogljivost okolja je malo ogrožena;

- $\quad$ razred 2 pomeni, da je pojav zmeren, opazen, zaznan, regeneracijska sposobnost je še vedno velika, obremenjenost pa zmerna, zmogljivost okolja je zmerno ogrožena; 

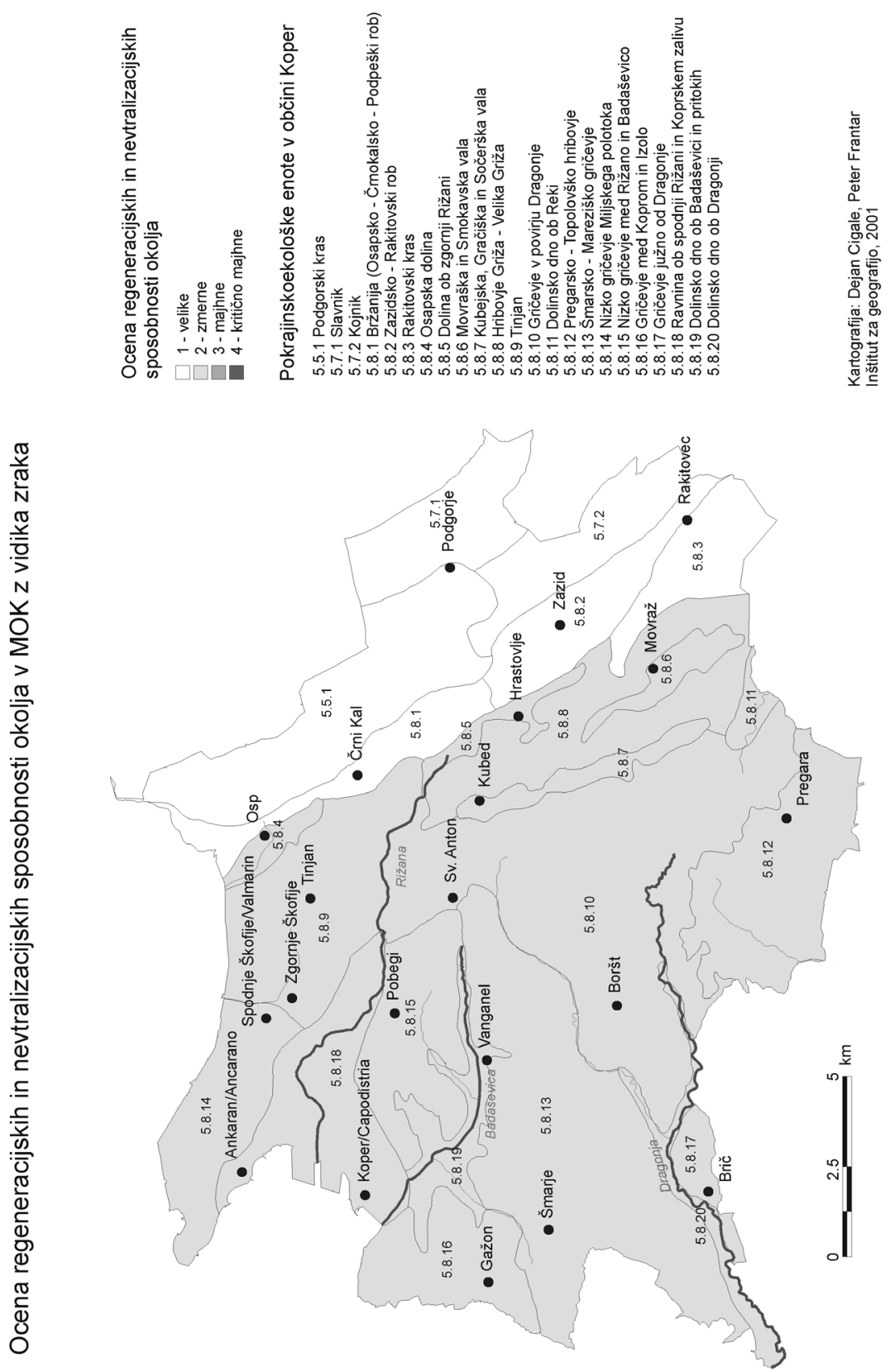

Karta 1: Regeneracijske sposobnosti ozračja v pokrsjinskoekeoloških enotah Mestne občine Koper 


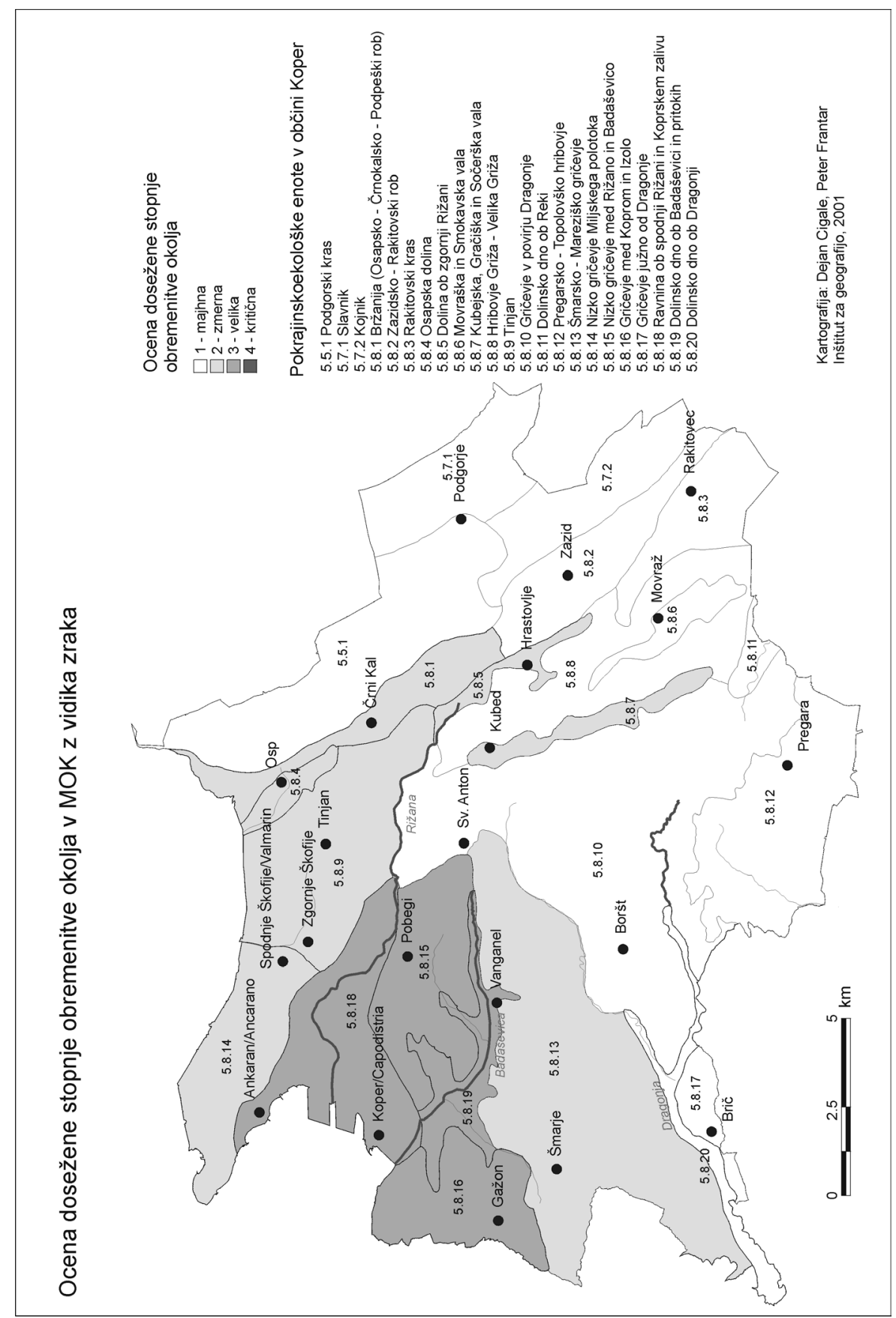

Karta 2: Obremenitve zraka v pokrajinskoekoloških enotah MOK 


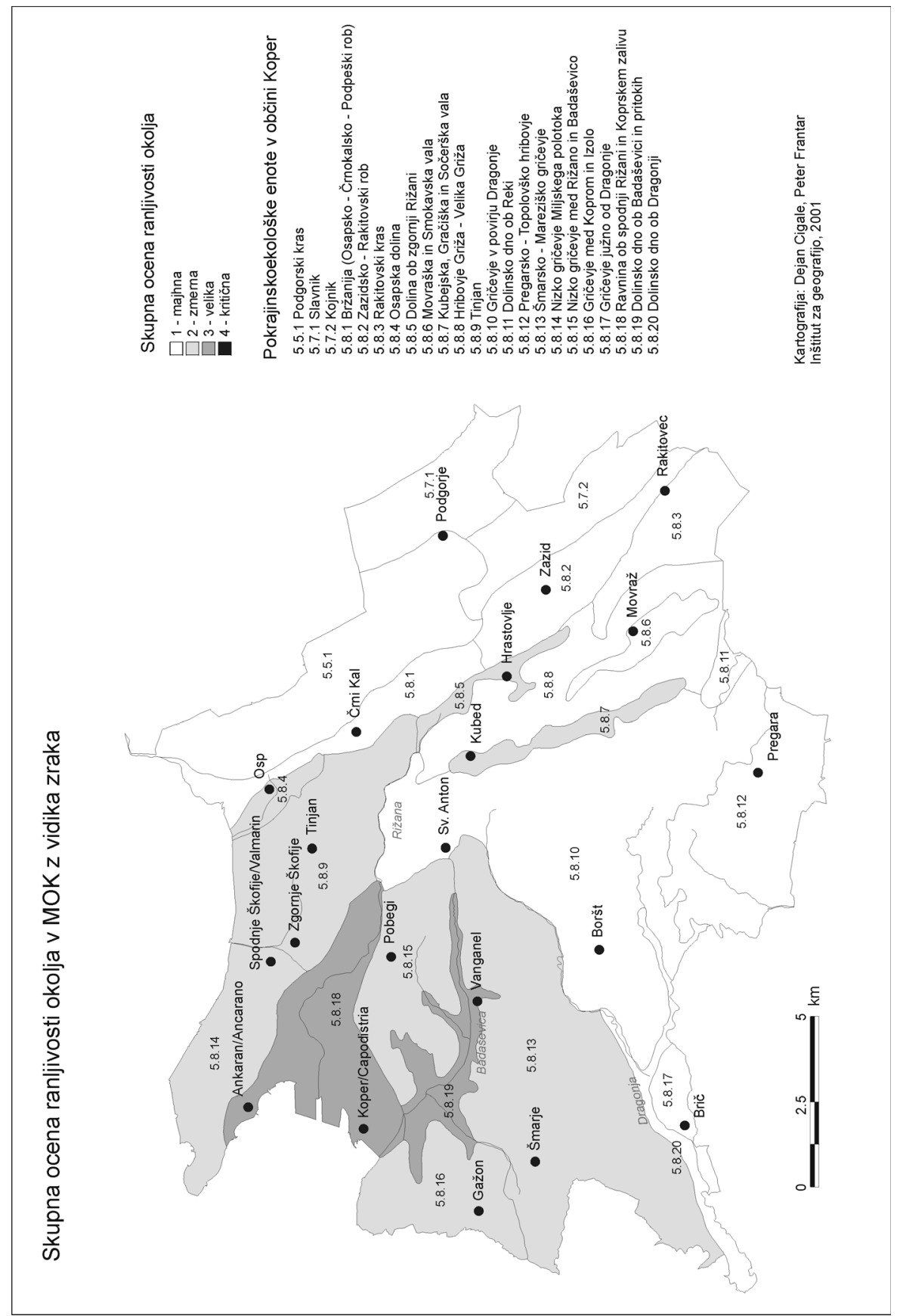

Karta 3: Ranljivost zraka v pokrajinskoekoloških enotah MOK 
- $\quad$ razred 3 označuje pojave, ki se pri količinski in kakovostni analizi pokažejo kot močni, zelo razširjeni, nosilnost okolja je zmerna ali majhna, obremenjenost pa že velika, zmogljivost okolja je že močno ogrožena;

- razred 4 pa pomeni zelo močne ali kritične vrednosti pri količinski in kakovostni analizi okolja, šibko oziroma zelo zmanjšano nevtralizacijsko sposobnost, zelo veliko ali kritično obremenjenost in zmogljivost okolja, ki je že kritično ogrožena (Špes et al., 1996).

Prispevek geografije pri načrtovanju sonarvnega razvoja na državni in lokalni ravni, je v tem, da smo izdelali eno od natančnih metodologij za zakonsko opredeljene študije ranljivosti, ki naj bi bile uporabljene tudi pri pripravi ustreznih podzakonskih aktov in predvsem $\mathrm{v}$ njeni neposredni aplikaciji na izbranih primerih. $Z$ dosedanjimi vzorčnimi študijami smo posegli v različne slovenske pokrajine (subpanonska, dinarska, alpska, mediteranska) in pokrajinske tipe (ravnine, gričevja, ozke doline, hribovje itd). Neposredno raziskovalno delo je pripomoglo tudi $\mathrm{k}$ sprotnemu preverjanju in dopolnjevanju metodologije. Opozorilo je na določene pomanjkljivosti in dileme ter zahtevalo spremembe in popravke pri izbranih kazalcih in tudi pri kriterijih njihovega razvrščanja $\mathrm{v}$ posamezne razrede. Izbor okoljsko pomembnih in relevantnih kazalcev, ki je vključen v metodologijo, ima uporabno vrednost tudi za izdelavo drugih, za preventivno načrtovanje, potrebnih dokumentov. Upoštevanje naših osnovnih metodoloških izhodišč, ki za oceno ranljivosti okolja zahteva jasno opredeljeno optimalno homogeno pokrajinsko enoto ter razumevanje delovanja spleta naravno- in družbenogeografskih okoljskih dejavnikov, bi preprečilo nastajanje površnih strokovnih ocen ali povzetkov poročil, ki se pogosto pojavljajo z naslovom študij ranljivosti okolja.

Dosedanje vzorčne lokalne študije ranljivosti okolja so pokazale veliko uporabno vrednost pri pripravi prostorskih planov občin, pri načrtovanju in pri presoji vplivov večjih posegov v okolje, pri vrednotenju primernosti dosedanjih posegov v neko okolje s specifičnimi samočistilnimi oziroma regeneracijskimi sposobnostmi. $\mathrm{Z}$ velikim številom pridobljenih podatkov, analiz, ekspertnih ocen o stanju pokrajinotvornih sestavin in o vseh okoljskih pritiskih so študije ranljivosti dobra informacijska podlaga za pripravo lokalnih in državnih poročil o stanju okolja, predvsem pa pri izdelavi načrtov za varstvo okolja na ravni občin. Izdelana in v praksi preverjena metodologija omogoča, da so rezultati strokovno optimalno objektivni in nudijo natančno oceno stanja okolja. Nenazadnje pa so podatki iz tovrstnih raziskav doslej tudi najustreznejša strokovna podlaga za ocenjevanje nosilnosti okolja (po Agendi 21) in načrtovanje sonaravnega razvoja. Za proučevana območja so namreč zbrani, urejeni, vrednoteni vsi obstoječi okoljski podatki in z razvrščanjem v razrede ovrednoteni tako, da omogočajo še širšo primerjavo. 
V preteklosti je precej strokovnih razprav in dvomov sprožala zakonska zahteva, da se ranljivost okolja ocenjuje za vnaprej določeno regijo (ekosistem, pokrajinskoekološko enoto). Izkazala se je namreč za manj primerno, ko je zahtevana večja natančnost oziroma točkovna informacija o stanju okolja in $\mathrm{s}$ tem ocena o njeni primernosti za določen poseg. Vendar pa ima takšna ocena pravo strokovno vrednost le, če temelji na kvantitativnih informacijah in ne le na ekspertnih ocenah oziroma na kakovostni analizi posrednih kazalcev. To pa je praksi težko izvedljivo, zato so za analizo stanja okolja, ob pomanjkanju neposrednih količinskih podatkov, najustreznejše nadomestilo ekspertne ocene. Strokovno korektna ekspertna ocena pa mora temeljiti na razumevanju pokrajine kot sistema součinkovanj vseh sestavin in upoštevati njihovo mrežno prepletenost in povezanost. Zato le delno sprejemamo očitke, da geografi včasih »razmažemo« oceno o ranljivosti okolja na pokrajinskoekološko enoto in je zato takšno informacija manj primerna za načrtovanje posega, ki je linijski ali omejen na manjši prostor. Naš odgovor je, da manjše homogene pokrajinskoekološke enote omogočajo večjo objektivnost ekspertnih ocen (ob pomanjkanju količinskih informacij), še posebej, če prostorske enote obravnavamo kot ekosisteme. Kljub temu pa bo potrebno metodologijo študije ranljivosti okolja dopolniti še z izborom kazalcev in ekspertnih ocen za načrtovanje posegov, ki vplivajo le na omejeni prostor znotraj pokrajinskoekološke enote.

Po odzivih neposrednih naročnikov dosedanjih študij ranljivosti okolja (občine ali skupine občin) ugotavljamo, da je njihova uporabna vrednost tudi pri spremljanju nastajajočih regionalnih razvojnih programov. Optimalno objektivne ocene o stanju okolja pa so pomembne tudi zato, ker nastajajo povsem neodvisno in neobremenjene od neposrednih načrtovalskih postopkov.

Pri bodočih študijah pa bomo morali narediti še korak naprej, da bomo neposredno soočili rezultate naših raziskav $\mathrm{z}$ načrtovanimi posegi v posamezne pokrajinskoekološke enote in $z$ vidika zmogljivosti okolja oceniti njihovo primernost. Aplikativnost teh študij bi povečali tudi z natančnejšo interpretacijo ocen ranljivosti okolja $\mathrm{z}$ vidika že sprejetih planskih dokumentov na lokalni ravni.

Večje število podatkov in strokovno ustreznejše kakovostne ocene bi zagotavljalo tudi sodelovanje specialistov ali pa celo večdisciplinarno sestavljena raziskovalna skupina. Doslej se je pokazala predvsem potreba po sektorskem preverjanju in vrednotenju kazalcev za samosčistilne, regeneracijske sposobnosti pokrajinotvornih sestavin. Obstoječe in nove vzorčne raziskave bomo morali pretehtati tudi v luči posebnih pogojev, ki jih za okoljsko občutljiva območja (obala, gorski svet, podeželje, kras, mesta) zahteva Nacionalni program varstva okolja (1999).

Ob spremembah v Zakonu o varstvu okolja (1993) se obeta, da bosta na novo opredeljena tudi vsebina in pomen študij ranljivosti okolja. Glede na 
njihov pomen pri načrtovanju sonaravnega razvoja in pri preventivnem planiranju pričakujemo, da bo to še naprej strokovno objektivna in kompleksna podlaga za usmerjanje prostorskega razvoja, kjer se okolje obravnava kot sistem medsebojnega součinkovanja njegovih sestavin. Pomembno pa je tudi, da študije še naprej izhajajo iz pokrajine in njene nosilne zmogljivosti, ne pa iz posegov, kjer bi bile v ospredju predvsem prostorske zahteve in potrebe posameznih dejavnosti.

\section{Literatura:}

Agenda 21 za Slovenijo, 1995: prispevek nevladnih organizacij. Umanotera, Slovenska fundacija za trajnostni razvoj, Ljubljana.

Brečko, V., Hočevar, M., Lampič, B., Natek, K., Plut, D., Smrekar, A., Šebenik, I., Špes, M., Vovk, A., 1996: Ranljivost okolja. V: Pak, M. (urednik), Spodnje Podravje s Prlekijo: Možnost regionalnega in prostorskega razvoja, 17. Zborovanje slovenskih geografov, Ptuj, Zveza geografskih društev Slovenije, Ljubljana, 53-108.

Čebulj, J., Pichler, D., Prančič, A., 1994: Zakon o varstvu okolja s komentarjem. Ljubljana, Gospodarski vestnik

Nacionalni program varstva okolja. Republika Slovenija, Ministrstvo za okolje in prostor, Uprava RS za varstvo narave. Ljubljana, 1998.

Park, C., 1997. The Environment: Principles and Applications. London and New York, Routledge, 30-52

Špes, M., Brečko, V., Hočevar, M., Lampič, B., Natek, K., Plut, D., Smrekar, A.A., Šebenik, I., Šubic, A., Vovk-Korže, A., 1996: Študija ranljivosti okolja: vsebina in metodologije kot osnova za pripravo podzakonskega akta: delovno gradivo. Inštitut za geografijo, Ljubljana.

Špes, M., Cigale, D., Lampič, B., Natek, K., Plut, D., Smrekar, A.A., VovkKorže, A., 1999: Ranljivost okolja kot omejitveni dejavnik prostorskega razvoja Slovenije: zaključno poročilo. Inštitut za geografijo, Ljubljana.

Špes, M., Cigale, D., Lampič, B., Natek, K., Smrekar, A., 2001: ranljivost okolja na območju mestne občine Koper. Inštitut za geografijo, Ljubljana.

Špes, M., Gabrovec, M., Bat, M., Hočevar, M., Natek, K., Natek, M., Plut, D., Sadar, K., Šebenik, I., 1995: Ranljivost okolja v novomeški občini: študija ranljivosti okolja in osnove za pripravo podzakonskega akta. Inštitut za geografijo, Ljubljana.

Špes, M., Hočevar, M., Natek, K., Natek, M., Šebenik, I., 1994: Študija ranljivosti okolja v občini Škofja Loka. Inštitu za geografijo, Ljubljana

Zakon o varstvu okolja. Uradni list RS 32/93, 17. 6. 1993. 


\title{
THE IMPORTANCE OF ENVIRONMENTAL VULNERABILITY STUDIES FOR THE SUSTAINABLE DEVELOPMENT OF SLOVENIA
}

\begin{abstract}
Summary
The studies of environmental vulnerability as determined by the Environmental Protection Act serve as the expert basis for the planning of sustainable development on both national and local levels and they are also intended to be a basis for the assessment of the impact of all major interventions into the environment. They should be imperative constituents of preventative conservation of the environment.

As maintaining the dynamic balance between the regenerative capacities of the environment and human interventions into it is the essence of sustainable development, the methodology of environmental vulnerability studies was also devised accordingly: on the one hand, the physico-geographical indicators have been evaluated which determine the self-purifying and neutralizing capacities or the carrying capacities of the environment and its landscape-forming constituents, and on the other hand, direct and indirect socio-geographical indicators have been analysed in order to assess the reached degree of burdening of individual environmental components, that is the general pollution or degradation. The assessment of the maximum acceptable degree of burdening proceeds from the relation between regenerative or neutralizing capacities of landscapeforming components and their pollution burdening.

The assessment of vulnerability of the environment and its constituents has been made for the optimally homogeneous landscape-ecological units, where numerous indicators have been taken into account in determining their regionalization, though the physico-geographical features of landscapes still predominate, while their functions are less important.

When dealing with individual elements, the interactive matrixes are applied where each of the indicators is determined by four classes, either quantitative or qualitative. Through matrix illustration of features of individual landscape elements, the studies are unified for all the local studies as concerns the methodology and contents. Equally, the optimum objectivity is thus guaranteed in the assessment of the state of environment, and a comparison is also possible of each of the data in a broader spatial dimension or a current comparison between individual landscape-ecological units. By clearly determined sizes of individual classes it is possible to avoid any unprofessional or deliberate boosting or reducing of the significance of individual data or information.

The earlier sample studies of environmental vulnerability made in different Slovenian landscape units (subpannonian, Dinaric, Alpine, Mediterra-
\end{abstract}


nean) and landscape types (plains, hills, narrow valleys, mountains, etc.) have contributed to a current testing and supplementing of the methodology. However, they also exposed certain weaknesses and dilemmas (e.g.: how to assess the vulnerability of several different water streams within a single landscapeecological unit). Nevertheless, the environmental vulnerability studies have proved their great applicability in preparing the spatial plans of municipalities, assessing the impacts of major interventions into the space, assessing the suitability of earlier interventions into a certain environment with specific (i.e. diminished) self-purifying capacities of the environment, etc. Last but not least, the results of such studies (made for Slovenian landscape features) have so far also been the most suitable expert basis for the assessment of carrying capacities of the environment (according to Agenda 21) and the planning of sustainable development. 